\title{
Simultaneous identification of A, B, D and $R$ genomes by genomic in situ hybridization in wheat-rye derivatives
}

\author{
E. SÁNCHEZ-MORÁN, E. BENAVENTE \& J. ORELLANA* \\ Unidad de Genética, Departamento de Biotecnología, ETSI Agrónomos, Universidad Politécnica de Madrid, \\ 28040-Madrid, Spain
}

\begin{abstract}
Multicolour genomic in situ hybridization was carried out in wheat-rye hybrids and in a wheat-rye translocation line. Different hybridization conditions and mixture compositions were used, and A, B and $\mathrm{D}$ genomes of hexaploid wheat as well as the $\mathrm{R}$ genome of rye were distinguished simultaneously in somatic cells. Combination of genomic and rDNA probes in multicolour in situ hybridization was also performed to identify chromosomes within a specific genome.
\end{abstract}

Keywords: genome identification, in situ hybridization, multicolour fluorescence, wheat-rye derivatives.

\section{Introduction}

Genomic in situ hybridization (GISH) (Pinkel et al., 1986) is a widely applicable cytogenetic technique for examining genome structure in interspecific hybrids and allopolyploid species. This approach uses labelled total genomic DNA as a probe to identify a genome or alien material in spread chromosome preparations. Usually, unlabelled genomic DNA from other species not used as probe(s) is added to the hybridization mixture to block common DNA sequences between the genomes (Jiang \& Gill, 1994, 1996; Anamthawat-Jónsson \& HeslopHarrison, 1996). Cross-hybridization is the most important limitation of the procedure and depends on sequence similarity among the genomes. Therefore, the discrimination is always easier between the chromosomes of different and distant genera than between chromosomes or genomes within the same genus.

The technique has been especially useful in the tribe Triticeae, in which it has been used extensively to identify alien chromatin introduced into wheat (Le et al., 1989; Friebe et al., 1996) in somatic cells and, in a few cases, to study wheat-rye chromosome pairing and recombination at meiosis (Miller et al., 1994; Fernández-Calvín et al., 1995; Benavente et al., 1996). However, the identification of the three genomes of hexaploid wheat is relatively more difficult because they

*Correspondence. E-mail: jorellana@bit.etsia.upm.es

(C) 1999 The Genetical Society of Great Britain. are closely related and, hence, have greater DNA sequence homology, leading to cross-hybridization. Thus, the identification of the A, B and D genomes of hexaploid wheat has only been reported by Mukai et al. (1993).

In the present work, we describe an improved reproducible multi-GISH method of identifying simultaneously all genomes of a given allopolyploid such as bread wheat, as well as introgressed alien chromatin in mitotic spreads.

\section{Materials and methods}

\section{Plant material}

For genomic probes and DNA blocking, the following diploid materials were used: Triticum monococcum L. ssp. boeoticum $(2 \mathrm{n}=2 x=14$, genome constitution AA); the Sitopsis species Aegilops bicornis Jaub. et Sp., Ae. longissima Schw. et Musch., Ae. searsii Feld. et Kis., Ae. sharonensis Eig. and Ae. speltoides Tausch. $(2 \mathrm{n}=$ $2 x=14$, genome constitution SS); Ae. squarrosa L. $(2 \mathrm{n}=2 x=14$, genome constitution DD); the inbred line R2 of rye, Secale cereale L. $(2 \mathrm{n}=2 x=14$, genome constitution RR).

The wheat-rye derivatives examined here were: wheatrye hybrids (genome constitution ABDR) obtained from the cross between bread wheat, $T$. aestivum L. cv. Chinese Spring, as female and the inbred line R2 as male, and the $1 \mathrm{BL} / 1 \mathrm{RS}$ wheat-rye translocation line M233. 


\section{Preparation of cells}

Seeds were germinated on moist filter paper for $48 \mathrm{~h}$ at room temperature. Primary roots $1 \mathrm{~cm}$ long were excised and immersed in tap water at $0^{\circ} \mathrm{C}$ for $24 \mathrm{~h}$. The root tips were fixed in 1:3 acetic acid-ethanol and stored for $2-4$ months at $4^{\circ} \mathrm{C}$. The fixed material was squashed, the cover slips were removed by freezing and the slides were air dried and stored at $4^{\circ} \mathrm{C}$ for $1-15$ days before in situ hybridization.

\section{DNA isolation and labelling}

The DNA isolated from all diploid materials was mechanically sheared to $10-12 \mathrm{~kb}$ pieces and then labelled with biotin-16-dUTP or digoxigenin-11-dUTP by nick translation (Boehringer Mannheim). Total genomic DNA was autoclaved for $5 \mathrm{~min}$ to give fragments of 100-200 bp and used at different concentrations as blocking DNA. The clone pTa71, a wheat $9 \mathrm{~kb}$ rDNA repeating unit (Gerlach \& Bedbrook, 1979) that contains the $18 \mathrm{~S}, 5.8 \mathrm{~S}$ and $26 \mathrm{~S}$ rRNA genes and intergenic spacer was used as the rDNA probe.

\section{In situ hybridization}

Before hybridization, slides were incubated in RNase A $(100 \mathrm{ng} / \mu \mathrm{L})$ and pepsin $(0.05 \%, w / v)$ in $10 \mathrm{~mm}$ $\mathrm{HCl}$, then fixed with formaldehyde $(1 \%, \mathrm{v} / \mathrm{v})$ and dehydrated in an alcohol series $(70 \%, 90 \%$ and $100 \%$ ). Labelled and blocking DNAs were denatured in the hybridization mixture, which contained $50 \%$ $(\mathrm{v} / \mathrm{v})$ deionized formamide and $10 \%(\mathrm{w} / \mathrm{v})$ dextran sulphate in $2 \times \mathrm{SSC}$ by heating at $80^{\circ} \mathrm{C}$ for $8 \mathrm{~min}$. Chromosomes were denatured in $70 \%$ deionized formamide- $2 \times \mathrm{SSC}-50 \mathrm{~mm}$ phosphate buffer, $\mathrm{pH} 7$, for $2 \mathrm{~min}$ at $80^{\circ} \mathrm{C}$, dehydrated in an ice-cold ethanol series $(70 \%, 90 \%$ and $100 \%, 3$ min each) and air dried. In situ hybridization was carried out overnight in a moist chamber at $42^{\circ} \mathrm{C}$. The concentration of each labelled probe in the different hybridization mixtures used was $10 \mathrm{ng} / \mu \mathrm{L}$ for $T$. monococcum and Aegilops Sitopsis species genomic DNA, $10-20 \mathrm{ng} / \mu \mathrm{L}$ for Ae. squarrosa, $1-2.5 \mathrm{ng} / \mu \mathrm{L}$ for rye genomic DNA and $5 \mathrm{ng} / \mu \mathrm{L}$ for pTa71 rDNA probe. After hybridization, the slides were washed in $1 \times \mathrm{SSC}$ (three times at $37^{\circ} \mathrm{C}$ and three times at $60^{\circ} \mathrm{C}, 5 \mathrm{~min}$ each) and subsequently rinsed in TNT (100 mM Tris-Cl, $\mathrm{pH} 7.5$, $150 \mathrm{~mm} \mathrm{NaCl}, 0.05 \%, \mathrm{v} / \mathrm{v}$, Tween 20) at room temperature (three times, $5 \mathrm{~min}$ each). Then, slides were blocked with $0.5 \%(\mathrm{w} / \mathrm{v})$ blocking reagent in $4 \times \mathrm{SSC}$ for $20 \mathrm{~min}$ at $37^{\circ} \mathrm{C}$.

\section{Inmunological detection and visualization}

Digoxigenin-labelled probes were revealed with $5 \mathrm{ng} / \mu \mathrm{L}$ goat anti-digoxigenin antibody conjugated with fluorescein isothiocyanate (FITC; Boehringer Mannheim), whereas biotinylated probes were detected with $5 \mathrm{ng} /$ $\mu \mathrm{L}$ avidin conjugated with Cy 3 dye (Amersham). Slides were screened using an Axiophot epifluorescent microscope (Zeiss) equipped with different sets of filters and photographed with Kodak Ektachrome film, ASA/ISO 400. The slide films were scanned and printed without further processing.

\section{Results and discussion}

The DNA of diploid rye was always used as a probe, whereas the DNA from the diploid species related to wheat genomes was used as blocking DNA or as probes in different experiments. In all cases, the rye genome was easy to identify even with low amounts of blocking DNA-probe $(4: 1)$.

Although A, B and D genomes have been identified by GISH previously (Mukai et al., 1993) using ratios of 80:1 (blocking-probes), in our study the ability to distinguish the three wheat genomes was poor, and the technique was poorly reproducible with ratios lower than 100:1. These results can be explained by the evolutionary relationships among the genomes. Thus, two genomes from distantly related species, such as rye and wheat, can be easily distinguished with little or no blocking DNA. However, when they are closely related, as occurs among wheat genomes, higher concentrations of blocking DNA are required (Anamthawat-Jónsson et al., 1990). Then, higher concentrations of unlabelled DNA were used, and a good discrimination among wheat genomes was obtained with ratios of 200-300:1 (blocking-probes).

The four genomes of wheat-rye hybrids can be distinguished in somatic cells using digoxigenin-labelled DNA from T. monococcum and S. cereale, biotinylated Ae. squarrosa DNA and the $\mathrm{S}$ genome from any species of the Sitopsis section as blocking DNA (Fig. 1a and b). Under these conditions, fluorescence hybridization signals were homogeneously distributed along the chromosomes. So, when observed through the microscope, the A genome was visualized as yellow-green fluorescence, the chromosomes belonging to the B genome were faint brown as a result of the slight cross-hybridization, the chromosomes of the D genome appeared red, and the chromosomes of the $\mathrm{R}$ genome were visualized by deep green fluorescence. The chromosomes of the A genome differed from those of the $\mathrm{R}$ genome because cross-hybridization occurred between the $\mathrm{A}$ and $\mathrm{D}$ genomes, and the deep green fluorescence, 


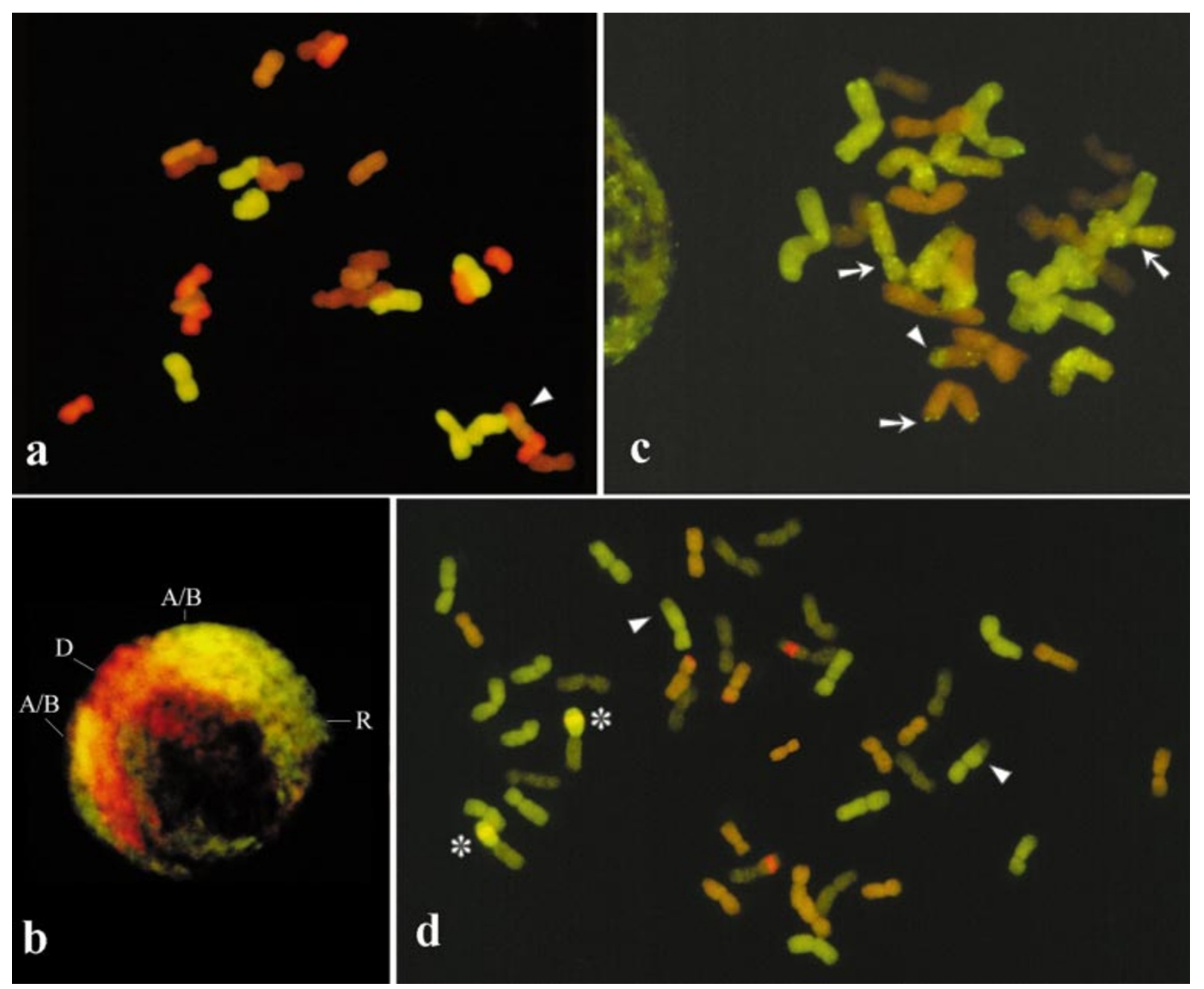

Fig. 1 Fluorescence micrographs of wheat-rye hybrids (a-c) and the translocation line M233 (d). (a) Mitotic metaphase with GISH identification of A genome (yellow-brown), B genome (brown), D genome (red) and R genome (yellow-green). (b) Somatic interphase in which genome identification is indicated. (c) Mitotic metaphase with GISH identification of A genome (red), B genome (yellow), D genome (brown) and R genome (green); arrows indicate bright scattered signals observed on wheat genomes. (d) Somatic metaphase with simultaneous GISH identification of A genome (green), B genome (brown), D genome (red) and R genome (bright green) and pTa71 probe (red) hybridization; asterisks indicate the 1BL/1RS translocated chromosomes. In (a), (c) and (d), arrowheads indicate the $4 \mathrm{AL} / 7 \mathrm{BS}$ translocation.

which should be observed on the chromosomes of the A genome, turned yellow-green. Slight colour differences in the printed copies can be obtained after the photographic process (Fig. 1a and b). Such a GISH pattern of genome discrimination has allowed several distinctively coloured chromatin domains to be revealed on interphase nuclei, which might reflect the somatic spatial arrangement of individual genomes in the wheat-rye hybrids (Fig. 1b).

When biotinylated DNA from T. monococcum and digoxigenin-labelled DNA from $\mathrm{S}$ genome species and $S$. cereale were used as probes, and unlabelled DNA from $A$ e. squarrosa was used for blocking, the A genome was visualized as red, B as yellow, D as faint brown and $\mathrm{R}$ as deep green (Fig. 1c). In this case, additional bright green scattered signals were observed mainly on chromosomes of the B genome, the most heterochromatic (Teoh \& Hutchinson, 1983), although small signals were also found in the other wheat genomes (Fig. 1c, arrows). Probably, S genome species possess one or more tandemly repeated sequences that are present as low-copy sequences in the $\mathrm{A}$ and $\mathrm{D}$ genomes. If the latter are used as probes and an $\mathrm{S}$ genome as blocking DNA, these sequences are blocked, and a homogeneous pattern of fluorescence is observed (Fig. 1a, $b$ and $d$ ). In contrast, if the $S$ genome is used as a probe, A or D genomes cannot block these repeated sequences and, consequently, a dotted hybridization pattern is found (Fig. 1c). The presence of such a

(C) The Genetical Society of Great Britain, Heredity, 83, 249-252. 
pattern would have great interest for identifying specific chromosomes within a given genome.

Genomic in situ hybridization has been used for detecting introgression of alien genetic material into wheat but, in all cases reported so far (Schwarzacher et al., 1992), only the DNA of a wild species was used as a probe and, therefore, localization of the alien chromatin on a specific wheat genome could not be made. As can be observed in Fig. 1d, we were able to identify the 1BL-1RS translocation of line M233 using genomic DNA and an rDNA probe. Moreover, the 4AL/7BS intergenomic translocation present in all allopolyploid wheat could be distinguished easily (Fig. 1, arrowheads). Thus, we have obtained unequivocal identification, not only of individual genomes but also of specific chromosomes, by a combination of multicolour genomic and repeated DNA probes.

It is worth mentioning that in situ hybridization patterns observed in this work were the same irrespective of which S genome was used as blocking DNA or as probe. This finding indicates that the ability of GISH to distinguish parental genomes of an allopolyploid has limitations when applied to very closely related genomes, such as those of the Sitopsis section.

To conclude, this work shows that simultaneous multicolour genomic and repeated DNA probe in situ hybridization is a very sensitive and accurate method of characterizing the genomes and the chromosomes involved in intergenomic translocations, and it is widely applicable in allopolyploids and interspecific hybrid combinations. Its potential for the analysis of the spatial arrangement of individual genomes is also presented.

\section{Acknowledgement}

This work has been supported by grant no. AGF960443 from the Comisión Interministerial de Ciencia y Tecnología (CICYT) of Spain.

\section{References}

ANAMTHAWAT-JÓNSSON, K. AND HESLOP-HARRISON, J. S. 1996. Establishing relationships between closely related species using total genomic DNA as a probe. In: Clapp, J. P. (ed.) Methods in Molecular Biology, Vol. 50, pp. 209-225. Humana Press, Totowa, NJ.
ANAMTHAWAT-JÓNSSON, K., SCHWARZACHER, T., LEITCH, A. R., BENNETT, M. D. AND HESLOP-HARRISON, J. S. 1990. Discrimination between closely related Triticeae species using genomic DNA as a probe. Theor. Appl. Genet., 79, 721-728.

BENAVENTE, E., FERNÁNDEZ-CALVÍN, B. AND ORELLANA, J. 1996. Relationship between the levels of wheat-rye metaphase I chromosomal pairing and recombination revealed by GISH. Chromosoma, 105, 92-96.

FERNÁNDEZ-CALVÍN, B., BENAVENTE, E. AND ORELLANA, J. 1995. Meiotic pairing in wheat-rye derivatives detected by genomic in situ hybridization and C-banding - a comparative analysis. Chromosoma, 103, 554-558.

FRIEBE, B., TUleEN, N. A., BADAEVA, E. D. AND GILl, B. S. 1996. Cytogenetic identification of Triticum peregrinum chromosomes added to common wheat. Genome, 39, 272-276.

GERLACH, W. L. AND BEDBRoOK, J. R. 1979. Cloning and characterization of ribosomal RNA genes from wheat and barley. Nucl. Acids Res., 7, 1869-1885.

JIANG, J. AND GILL, B. S. 1994. Different species-specific chromosome translocations in Triticum timopheevii and T. turgidum support the diphyletic origin of polyploid wheats. Chrom. Res., 2, 59-64.

JIANG, J. AND GILL, B. S. 1996. Current status and potential of fluorescence in situ hybridization in plant genome mapping. In: Paterson, A. H. (ed.) Genome Mapping in Plants, pp. 127-135. R.G. Landes Co., Austin, TX.

LE, H. T., ARMSTRONG, K. S. AND MIKI, B. 1989. Detection of rye DNA in wheat-rye hybrids and wheat translocation stocks using total genomic DNA as a probe. Plant Mol. Biol. Report, 7, 150-158.

MILLER, T. E., READER, S. M., PURDIE, K. A. AND KING, I. P. 1994. Determination of the frequency of wheat-rye chromosome pairing in wheat $\times$ rye hybrids with and without chromosome 5B. Theor. Appl. Genet., 89, 255-258.

MUKAI, Y., NAKAHARA, Y. AND YAMAMOTO, M. 1993. Simultaneous discrimination of the three genomes in hexaploid wheat by multicolor fluorescence in situ hybridization using total genomic and highly repeated DNA probes. Genome, 36, 489-494.

PINKel, D., STRAume, T. AND GRAy, J. W. 1986. Cytogenetic analysis using quantitative, high-sensitivity, fluorescence hybridization. Proc. Natl Acad. Sci. U.S.A., 83, 2934-2938.

SCHWARZACHER, T., ANAMTHAWAT-JÓNSSON, K., HARRISON, G. E., ISLAM, A. K. M. R., JIA, J. Z., KING, I. P. ET AL. 1992. Genomic in situ hybridization to identify alien chromosomes and chromosome segments in wheat. Theor. Appl. Genet., 84, 778786.

TEOH, S. B. AND HUTCHINSON, J. 1983. Interspecific variation in C-banded chromosomes of diploid Aegilops species. Theor. Appl. Genet., 65, 31-40. 